\title{
Implementasi Nilai Pendidikan Karakter pada Anak Sekolah Dasar
}

\author{
Nur Fatimah \\ Sekolah Tinggi Agama Islam YPBWI Surabaya \\ Email: nurfatimah2910@gmail.com
}

\begin{abstract}
Abstrak
Wacana akan terjadinya diintegrasi karakter masyarakat dalam beberapa dekade ini tampaknya mendekati kenyataan. Dalam kondisi semacam ini menjadi perlu adanya pendidikan karakter yang baik dan harus diaplikasikan sejak masa golden age. Mengapa demikian? Jawaban dari persoalan ini menjadi kajian utama dalam artikel ini. Penelitian ini mendapati bahwa para ahli prikologi menilai bahwa pendidikan karakter sudah harus semestinya dari dalam keluarga, karena keluarga merupakan lingkungan pertama bagi pertumbuhan anak. Selain itu, pendidikan karakter juga perlu diberikan kepada anak-anak saat masuk dalam lingkungan sekolah dan masyarakat. Penekanan usia dini menjadi penting sebab pada usia tersebut nilai-nilai religius, jujur, toleransi, disiplin, kerja keras, kreatif, mandiri, demokratis, rasa ingin tahu, semangat kebangsaan, cinta tanah air, menghargai prestasi, bersahabat, cinta damai, gemar membaca, peduli lingkungan, peduli sosial dan tanggung jawab mulai terbentuk dan tertanam dalam alam bawah sadar mereka.
\end{abstract}

Kata kunci: Karakter; golden age; labelling anak; disintegrasi nilai; tanggung jawab.

\section{Pendahuluan}

Meskipun perkembangan teknologi dan ilmu pengetahuan memberi dampak baik, di lain hal itu juga memunculkan persoalan tersendiri. Perkembangan tersebut akan berdampak pada terjadinya ketergerusan nilainilai akhlak yang ada pada diri manusia yang meruncing menjadi satu budaya yang dihasilkan. Kandungan budaya tersebut dapat terdiri dari nilainilai religiositas maupun nilai-nilai hedonis murni dari persinggungan manusia dengan manusia lain, maupun dengan alam secara luas. Hal ini dapat menyebabkan indikator kesuksesan maupun kemajuan menjadi sangat ditentukan oleh materi dengan mengesampingkan tolak ukur nilai akhlak maupun budi pekerti. Oleh karena itu, tidak mengherankan apabila bermunculan beberapa persoalan masyarakat yang berkembang saat ini berawal dari sifat-sifat tercela, keserakahan meluas, ketidakjujuran 
berkembang, tidak bertanggung jawab, hilangnya serta nilai-nilai religius dan sifat positif lainnya mulai menghilang.

Kondisi tersebut menjadikan manusia seolah-olah dikelilingi oleh pelbagai perkembangan teknologi yang sangat pesat serta perubahan ilmu pengetahuan ataupun ilmu teknologi, yang tidak hanya menyuguhkan suatu kenyamanan atau kemudahan, tetapi juga menyajikan beberapa hal yang cukup mengkhawatirkan. Selain itu, dengan adanya teknologi juga dapat mengurangi nilai-nilai kemanusiaan yang melekat pada diri manusia secara umum. Kemanjuan yang terjadi saat ini, semula dapat dipandang akan menjadikan pekerjaan manusia lebih mudah, namun pada kenyataannya malah memunculkan pelbagai rasa resah, sepi, terasing dan takut bagi umat manusia secara luas, khususnya umat Islam. Persoalan rasa tersebut ditandai dengan terkikisnya, bahkan hilangnya rasa kebersamaan, silaturrahim dan solidaritas antarsesama. Contohnya adalah penemuan dalam bidang elektronik seperti televisi, game play station, komputer maupun hand phone. Dengan adanya penemuan ini mengakibatkan sebagian masyarakat bahkan pada kalangan anak-anak hingga pada orang dewasa lebih tertarik dan terkokuskan pada layar tersebut sehingga mengabaikan lingkungan sekitarnya. ${ }^{1}$

Dalam keadaan semacam ini maka menjadi satu keniscayaan untuk menghadirkan satu pendidikan karakter yang baik dan harus diaplikasikan sejak masa golden age-nya. Bagimana caranya? Mengapa demikian? Jawaban dari persoalan tersebut akan membuktikan apakah artikel ini layak untuk dikaji atau sebaliknya.

\section{Definisi}

Kesimpulan saat melakukan wawancara bersama dengan Bapak Andre selaku kesiswaan di sekolah dasar Khazanah Ilmu, memang anak sekarang itu banyak yang memiliki karakter atau akhlak yang baik. Akan tetapi memang ada beberapa yang memiliki akhlak yang tidak sesuai dengan sebaimana semestinya. Oleh karena itu pengenalan sekaligus pemahaman terhadap nilai-nilai karakter yang posisif menjadi sangat penting bagi perkembangan masyarakat luas. ${ }^{2}$ Persoalannya menjadi apa sebenarnya pendidikan karakter itu, sehingga ia tampak begitu penting?

Salim Haitami dalam karyanya yang berjudul Pendidikan Karakter: Konsepsinya terpadu di Lingkungan Keluarga, Sekolah, Perguan Tinggi, Masyarakat sedikit banyak menyinggung persoalan ini. Menurutnya, pendidikan memiliki satu pengertian yang sangat bervariasi. Ia mencakup pelbagai aktivitas maupun sikap masyarakat dari generasi ke generasi

\footnotetext{
${ }^{1}$ Jumarudin et al., "Pengembangan Model Pembelajaran Humanis Religius", Pengembangan Pendidikan, vol. 2, no. 2, (2014), 117-118.

${ }^{2}$ Andre (Guru SD Khazanah Ilmu), Wawancara, Sidoarjo, 23 oktober 2018.
} 
selanjutnya, yang bertujuan mentransfer pengetahuan, keterampilan dan nilai-nilai lain yang telah ada kepada generasi selanjutnya. Oleh karena itu, usaha ini dapat diartikan sebagai satu upaya mempersiapkan pesertas didik untuk mampu menerapkan fungsi hidup secara baik, secara lahiriyah maupun batiniyah. ${ }^{3}$

Penjelasan di atas, menggambarkan bahwa proses pendidikan dapat dikategorikan menjadi dua. Pertama, pendidikan dalam arti luas, yaitu proses yang berkaitan dengan, individu, masyarakat dan alam semesta secara luas. Kedua pendidikan secara sempit dapat diartikan secara khusus sebagai proses transfer ilmu dan nilai-nilai kepada peserta didik yang diimplementasikan oleh satu institusi tertentu guna mengantarkan murid kepada masa dewasanya. Meskipun kedua definisi tersebut tampak berbeda, sejatinya keduanya menghasilkan satu kesimpulan yang sama, yaitu tujuan yang dihasilkan adalah tercapainya rasa bahagia dengan berlandas pada nilai-nilai luhur yang disepakati bersama. ${ }^{4}$

Adapun itu, istilah karakter yang dalam bahada inggrir character berasal dari istilah yunani, character yang memiliki arti membuat tajam atau membuat dalam. Karakter juga dapat berarti dapat memiliki arti mengukir sifat utama dari ukuran adalah melekat kuat di atas benda yang diukir. Oleh karena itu,karakter adalah ciri khas seseorang dan karakter tidak dapat dilepaskan dari konteks sosial budaya dikarenakan karakter sendiri ternbentuk dari lingkungan budaya dan sosial tertentu. ${ }^{5}$

Kamus Besar Bahasa Indonesia menerjemahkan karakter sebagai suatu istilah yang menggambarkan keadaan jiwa, budi pekerti dan akhlak seorang individu yang sangat berkaitan erat dengan sosial masyarakat. ${ }^{6}$ Menindaklanjuti hal tersebut Salim Haitami dalam karyanya Pendidikan Karakter: Konsepsinya terpadu di Lingkungan Keluarga, Sekolah, Perguan Tinggi, Masyarakat mengartikan karakter sebagai satu term yang sangat terkait dengan hal-hal semacam motivasi (motivation), keterampilan (skill), perilaku (behavior) dan sikap (attitude). Dalam hal ini karakter diartikan sebagai seperangkat keinginan menunaikan suatu hal terbaik, sesuai kapasitas intelektual, kritis dan didukung dengan sikap jujur, bertanggung jawab, berprinsip kuat, adil dan memegang nilai-nilai moralitas yang berlaku. $^{7}$

\footnotetext{
3 Salim Haitami, Pendidikan Karakter: Konsepsinya terpadu di Lingkungan Keluarga, Sekolah, Perguan Tinggi, Masyarakat (Yogyakarya: Ar-Ruzz Media, 2013), 31.

${ }^{4}$ Ibid., 27.

${ }^{5}$ Ibid., 28.

${ }^{6}$ Departement Pendidikan Nasional, Kamus Besar Bahasa Indonesia (Jakarta: Gramedia Pustaka Utama, 2011), 623.

${ }^{7}$ Haitami, Pendidikan Karakter, 29.
} 
Sebagai satu perangkat tanggapan atau reaksi individu terhadap rangsangan atau lingkungan, karakter seseorang tidak bisa dilepaskan dari hubungannya dengan Tuhan dan manusia. Oleh karena itu, karakter sangat erat hubungannya sikap dan perilaku yang saling terkait antara diri, masyarakat dan lingkungan secara luas. Ia sangat dipengaruhi oleh rasa kemanusiaan yang diwujudkan dalam bentuk sikap, pola pikir, ungkapan, rasa, karsa dan aksi. Kesemua hal tersebut saling berkaitan dengan seperangkat norma yang berlaku di masyarakat. Setiap personal yang memiliki karakter baik dan unggul sudah sewajarnya selalu menerapkan dan memiliki motivasi besar dan selalu berusaha secara maksimal utamanya yang berkaitan dengan nilai-nilai agama, manusia dan lingkungan secara luas berbangsa maupun negara. Segala potensi ini harus diimplementasikan secara optimal dengan dibekali pengetahuan dan kesadaran akan diri, perasaan dan emosi pribadi. ${ }^{8}$

Jadi pada hakikatnya karakter seorang individu merupakan hasil kolaborasi antara sikap, kebiasaan dan perilaku yang dipilih, dipilah, diputuskan serta dikerjakan dalam kesehariannya. Akhirnya, karakter adalah satu kapasitas yang melekat pada diri individu sebagai produk kebiasaan dalam hidup yang ia jalani seiring berjalannya waktu sampai orang tersebut tidak menyadari akan seperti apa dirinya sendiri. Meskipun demikian, karakter tidak melulu tersembunyi, sebaliknya ia dapat dinilai oleh orang lain. ${ }^{9}$

Kebiasaan dalam hidup merupakan cerminan perilaku yang terbentuk dari akumulasi perbuatan dan aktivitas lain yang selalu terulang setiap hari. Aktivitas tersebut mulanya dilakukan secara sadar dan sengaja. Dalam perkembangannya proses ini terjadi berulang-ulang hingga akhirnya para pelaku tidak sadar akan kebiasaan apa yang ia lakukan konsisten. Bahkan ia akan melakukan kebiasaan tersebut dan menganggapnya sebatas refleks yang dilakukan secara tidak sadar. Jika dilihat dari sisi filosofis maka hal ini dapat diartikan sebagai cerminan pola pikir, respons, bahkan pemahaman di alam bawah sadar akan suatu hal. Terlepas dari itu semua, berangkat dari penjelasan di atas maka dapat disimpulkan bahwa pikiran, keinginan bahkan kebiasaan sejara gradual akan berakhir pada terbentunya satu karakter tertentu. ${ }^{10}$ Oleh karena itu, tidak mengherankan kalau Zubaedi merangkum hal-hal yang berkaitan dengan karakter menjadi aspek kognitif (cognitive), rasa (feeling) dan perbuatan (action). ${ }^{11}$

\footnotetext{
${ }^{8}$ Ibid.

${ }^{9}$ Ibid., 29-30.

${ }^{10}$ Ibid., 30.

11 Zubaedi, Desain Pendidikan Karakter: Konsepsi dan Aplikasinya dalam Lembaga Pendidikan (Jakarta: Kencana, 2011), 25.
} 
Dari pelbagai penjabaran tersebut di atas, maka ditemukan bahwa pendidikan karakter merupakan satu hal yang sangat penting. Hal ini diperkuat dengan ditemukannya pelbagai kajian yang menghasilkan kesimpulan bahwa karakter seorang individu sangat berpengaruh terhadap kesuksesan yang ada pada diri orang itu. Ini terjadi karena kesuksesan pada seseorang tidak dipandang dari ilmu pengetahuan belaka (hard skill), akan tetapi ada unsur lain yang berperan lebih besar, yaitu kemampuan dalam mengendalikan dan mengatur diri sendiri, orang lain maupun lingkungan secara luas (soft skill). Selain itu, pendidikan karakter juga dapat mempengaruhi prestasi akademik dari seorang anak. Dengan adanya pendidikan karakter dapat menjadikan anak menjadi cerdas secara emosi. Dengan kecerdasaan emosi ini lah bisa dijadikan sebagai bekal untuk masa depan individu dalam menghadapi pelbagai permasalahan termasuk persoalan akademik. $^{12}$

Pendidikan karakter sebenarnya tidak hanya dibutuhkan pada lingkungan sekolah saja, ia juga diperlukan dalam ruang lingkup keluarga dan lingkungan sosial yang ada pada masyarakat. Di Indonesia saat ini, pendidikan karakter sedang digiatkan sebagai upaya terus-menerus untuk membangkitkan dan mengokohkan mentalitas seluruh masyarakat Indonesia. ${ }^{13}$

\section{Nilai-Nilai dalam Pendidikan Karakter}

Implementasi pendidikan karakter dapat dijalankan melalui pelbagai macam proses penanaman nilai-nilai kebajikan yang telah mengakar dalam diri seluruh masyarakat di Indonesia. Hal itu karena pada dasarnya pendidikan ini merupakan satu proses mengembangkan diri, melalui penanaman nilai-nilai positif yang berasal dari pandangan hidup, ideologi dan pola pikir bangsa Indonesia yang tercermin dalam budaya yang ada. Dalam karakter ada beberapa beberapa sumber nilai patut diperhatikan. Pertama bersumber dari agama. Indonesia dengan segala variasi masyarakatnya yang ada di dalamnya secara tidak langsung terikat dengan satu nilai yang sama, yaitu nilai yang berasal dari keyakinan ideologisnya, agama. Beragama sejatinya dapat diartikan sebagai proses penanaman dan pengamalan nilai-nilai yang terkandung di dalamnya, tidak terkecuali karakter yang terbentuk sebagai konsekuensi logis darinya. ${ }^{14}$ Kedua nilai pancasila. Nilai ini berperan sebagai hukum yang mengatur keberlangsungan negara di mana masyarakat dapat hadir dan berkembang ke depannya.

\footnotetext{
${ }^{12}$ Haitami, Pendidikan Karakter, 32.

${ }^{13}$ Ibid., 39.

${ }^{14}$ Imron Mustofa, "Ulama' dan Kontestasi Pengetahuan dalam Sudut Pandang Al Qur'ān", Jurnal Pendidikan Agama Islam (Journal of Islamic Education Studies), vol. 5, no. 1 (2017), 73-76.
} 
Ketiga nilai budaya. Nilai ini menjadi barometer yang harus dijaga agar tidak terjadi kesenjangan dalam masyarakat. Keempat jika ditinjau dari tujuan pendidikan nasional, dapat dilihat ada delapan belas nilai yang harusnya dimiliki oleh seluruh pihak yang berhubungan dengan proses pendidikan di Indoensia.

Delapan belas nilai dalam pendididkan karakter itu meliputi: pertama, sikap religius. Yang dimaksud di sini adalah segala sikap, komitmen dan tindakan untuk tetap taat dalam menjalankan nilai-nilai yang diajarkan oleh agama yang diikuti. Salah satu nilai tersebut tercermin dalam bentuk sikap toleran terhadap pelbagai proses pelaksanaan ibadah pemeluk agama lain yang dilakukan oleh para pemeluknya. Jika hal ini dapat diimplementasikan dengan baik, maka seluruh masyarakat akan tetap terkumpul secara rukun dan tentram meskipun mereka memiliki keyakinan yang berbeda. Kedua, jujur yaitu satu sikap untuk menghadirkan individu sebagai sosok yang ucapan dan perbuatannya dapat dipercaya. Ketiga, toleran yaitu perbuatan yang bertujuan untuk saling menghargai perbedaan suku, ras, agama, pendapat dan sikap sesama masyarakat utamanya yang berbeda dengan dirinya sendiri. Keempat, disiplin yaitu merupakan sikap yang menujukan sikap tertib dan patuh atas peraturan yang ada dan telah ditetapkan. Kelima, kerja keras. Hal ini diwujudkan dalam bentuk sikap sungguh-sungguh dalam menghadapi pelbagai persoalan baik berupa tanggung jawab individu, institusi atau masyarakat secara luas. ${ }^{15}$

Keenam, kreatif yaitu berpikir dan disertai dengan tindakan agar dapat menghasilkan suatu benda yang baru dari sesuatu yang pernah dimilikinnya. Ketujuh mandiri yaitu merupakan tindakan yang dilakukan secara sendiri tidak mudah bergantung ketika menyelesaikan suatu tugas dan menyelesaikannya sendiri. Kedelapan, demokratis dalam pola pikir, sikap dan perbuatan. Ini diterapkan dalam memandang hak dan kewajiban sebagai individu sekaligus bagian dari masyarakat berbangsa dan negara. Kesembilan, rasa ingin tahu yaitu merupakan sikap untuk mengetahui lebih dalam atas apa yang telah ia ketahui atau lihat. Kesepuluh, semangat kebangsaan merupakan sikap atau tindakan, wawasan dengan mengutamakan kemaslahatan publik bernegara di atas kepentingan pribadi. Kesebelas, cinta tanah air yaitu merupakan sikap atau prilaku, wawasan anak yang mengutamakan kepentingan bangsa di atas kepentingan pribadi atau kelompok. Kedua belas, sikap saling menghargai prestasi yang dicapai orang lain. Sikap ini tercermin dalam perbuatan yang mendukung individu untuk berprestasi dan bermanfaat bagi masyarakat secara luas. Ketiga belas, bersahabat dan komunikatif yang merupakan sikap atau perilaku. Keduanya

${ }^{15}$ Zubaedi, Desain Pendidikan, 74-76.

112 Jurnal El-Banat 
mencerminkan rasa suka berkomunikasi, gaul antarsesama. Keempat belas, cinta damai berupa perilaku maupun sikap menjadikan personal untuk dapat merasa bahagia, senang atas wujud eksistensi individu. ${ }^{16}$

Kelima belas, gemar membaca. Karakter ini ditujukan untuk memicu dorongan internal individu dalam dirinya masing-masing agar mampu dan mau meluangkan waktunya guna membaca pelbagai materi yang tersedir tentunya yang mampu memicu dirinya untuk lebih baik. Keenam belas, rasa peduli terhadap lingkungan sekitar. Rasa ini diimplementasikan dalam pelbagai bentuk aktivitas guna menjaga atau melestarikan alam dengan cara mencegah kerusakan dan membetulkan segala persoalan alam. Ketujuh belas, keterpedulian sosial. Sikap ini dapat diwujudkan dalam bentuk perilaku yang dapat memacu peserta didik untuk memiliki rasa ingin membantuk orang lain dalam kehidupan bermasyarakat utamanya yang paling memerlukan. Kedelapan belas, rasa bertanggungjawab. Hal ini sejatinya merupakan perilaku yang ingin dimunculkan guna menjaga semangat siap menghadapi pelbagai persoalan. Masalah-masalah tersebut dapat dimanivestasikan dalam pelbagai aktivitas yang berkaitan dengan tanggung jawab personal, maupun yang berkaitan dengan sosial masyarakat, lingkungan, alam, kebudayaan, negara ataupun yang berkaitan dengan Tuhan. kedelapan belas nilai tersebut masih dapat ditambahkan maupun dikurangi sesuai dengan kebutuhan dari seorang anak tersebut. ${ }^{17}$

\section{Pusat Pendidikan Karakter}

Secara struktural dalam usaha membangun karakter seorang anak dapat dimulai dari lingkungan keluarga anak tersebut. Sebagai lingkungan pendidikan informal keluarga merupakan faktor penting selain sekolah dan masyarakat luas. Adapun lingkungan formal dalam pendidikan karakter dihuni oleh sekolah. Lebih luas dari itu sosio-masyarakat menjadi wilayah pendidikan individu anak yang sifatnya non-formal dalam artian tidak dapat dibentuk secara sepihak namun harus melalui proses membaca, memilih, memilah dan implementasi. Sebagai lingkungan paling sempit ruang lingkupnya, keluarga adalah bentuk kecil dari gambaran masyarakat luas, yang tersusun dari pelbagai corak individu dan kelompok dengan pelbagai ciri khasnya masing-masing meskipun meskipun masih dalam satu payung yang sama, yaitu satu keadaan yang saling membutuhkan satu sama lainnya. Ini dinyatakan secara jelas dalam Kamus Besar Bahasa Indonesia. Dalam buku tersebut dinyatakan bahwa keluarga haruslah tersusun dari ayah, ibu, anak serta seluruh elemen lain yang hadir dalam rumah tangga itu. ${ }^{18}$

\footnotetext{
${ }^{16}$ Ibid.

${ }^{17}$ Ibid.

${ }^{18}$ Nasional, Kamus Besar, 659.
} 
Dilansir dari Badan Kependudukan dan Keluarga Berencana Nasional (BKKBN), indealnya keluarga harus memiliki beberapa fungsi. Fungsi-fungsi itu terdiri dari delapan hal. Pertama, fungsi agama, maksudnya segala aktivitas dalam keluarga sejatinya harus berpijak di atas satu nilai agama tertentu. Implementasi hal tersebut dapat dikatakan sebagai salah satu fungsi terpenting dibanding yang lainnya. Sebab dalam agama diajarkan pelbagai nilai-nilai, seperti nilai toleransi. Sikap toleran bagi seorang anak didik terhadap lingkungannya memainkan peran vital, utamanya dalam lingkungan masyarakat yang terdiri dari pelbagai macam agama, suku, budaya, serta keanekaragaman lainnya. Kedua, fungsi sosial budaya yaitu keluarga merupakan temoat penanaman nilai-nilai budaya yang menjadi panutan selama ini. Ketiga, fungsi cinta kasih yaitu keluarga merupakan tempat penananman cinta kasih sayang kepada seorang anak dalam kehidupan berkeluarga, sosio-masyarakat, bangsa maupun bernegara. ${ }^{19}$

Keempat, fungsi perlindungan yaitu keluarga merupakan tempat yang menciptkana suasana aman, damai, nyaman, serta adil bagi diri anak tersebut. Kelima, fungsi reproduksi yaitu dalam satu keluarga khususnya pada anak harus didik untk dapat mengerti dan memahami pentingnya gaya, pola dan cara hidup yang sehat, terutama yang berkenaan dengan alat-alat reproduksi. Mereka harus tahu betapa vital kesehatan itu bagi keberlangsungan hidup ke depannya. Keenam, fungsi pendidikan dalam keluarga. Fungsi ini sejatinya merupakan wilayah terbaik bagi seorang anak dalam mempelajari cara dan nilai-nilai yang harus diperhatikan dalam perjalanan kehidupan sosial dan pendidikannya. Sebenarnya, pendididkan pada keluarga merupakan suatu pusat pendidikan yang berdampak besar dalam usaha membangun fondasi dasar serta memberikan pengalaman yang begitu berharga dalam perkembangan individu anak itu. Sementara itu, lingkungan sekolah maupun lingkungan masyarakat hanyalah pengembangan lanjutan dari pendidikan yang diperoleh dalam keluarga. Ketujuh, fungsi lingkungan. Di sini ditekankan nilai-nilai bahwa keluarga adalah tempat mencipta suatu keharmonisan dalam masyarakat maupun alam semesta secara luas. ${ }^{20}$

Dari beberapa penjelasan yang terkait fungsi-fungsi tersebut dapat dipahami bahwa keluarga sejatinya merupakan elemen terpenting yang dalam menumbuhkan nilai-nilai karakter dalam diri peserta didik hingga ia dewasa. Karakter yang diproses dengan baik, akan terbentuk menjadi satu sikap dan perilaku yang baik pula. Adapun dasar pendidikan karakter itu sebaiknya ditanamkan dan diperkuat sejak usia dini (golden age). Pada

\footnotetext{
${ }^{19}$ Haitami, Pendidikan Karakter, 43-46.

${ }^{20}$ Ibid.
}

114 Jurnal El-Banat 
rentang usia ini segala aktivitas kehidupan akan sangat berpengaruh kuat dalam perkembangan potensi dan kemampuan anak ke depannya. Oleh karena itu, keluarga adalah satu unsur penting dalam memunculkan individu dalam masyarakat yang berkarakter baik. ${ }^{21}$

Selanjutnya lingkungan sekolah. Lingkungan sekolah juga memperngaruhi dan menentukan karakter pada diri anak. Pendididkan karakter anak dalam lingkungan sekolah semestinya mampu menciptakan sikap dan prilaku anak yang penuh akan nilai-nilai positif, baik secara kognitif, afektif maupun psikomotorik. Hal ini penting guna menghadirkan seorang anak yang memiliki pengetahuan, pemahaman dan pengalaman menerapkan nilai-nilai positif dalam lingkungan yang sesungguhnya. Pendidikan anak dalam lingkungan sekolah dapat diaplikasikan dalam pembelajaran pada tiap-tiap mata pelajaran. Caranya dapat dilakukan dengan menyelipkan norma maupun nilai-nilai positif yang berlaku dalam masyarakat dan selayaknya mampu direlasikan dengan kehidupan seharihari. Selain itu ada juga lingkungan pendidikan masyarakat. Masyarakat merupakan lingkungan pendidikan yang sangat bagi anak dengan sifanya yang non-formal. Masyarakat seharusnya juga ikut terjun serta berperan dalam pendidikan karakter anak. Dalam persoalan ini masyarakat juga harus ikut serta bertanggung jawab untuk menciptakan lingkungan yang mendukung dan nyaman bagi peserta didik. ${ }^{22}$

Dalam proses pendidikan semacam ini, orang tua seharusnya selektif dalam memilih lingkungan yang baik secara mendukung bagi diri anak serta menghindari lingkungan yang dapat membawa anak pada hal yang negatif. Ketika seorang anak mulai tumbuh dan berkembang dalam suatu lingkungan yang kurang baik, maka secara otomatis dalam diri individu tersebut akan terbentuk nilai-nilai yang kurang baik, baik itu berupa karakternya dalam bersikap, berkomunikasi maupun dalam aktivitas lain. Sama halnya dengan lingkungan di sekolah juga perlu memilih lingkungan masyarakat yang baik supaya dapat mendukung proses pendidikan anak tersebut.

\section{Implementasi Pendidikan Karakter dalam Lingkungan Keluarga}

Seperti yang telah diketahui sebelumnya, bahwa fungsi keluarga adalah sebagai pendidik. Keluarga adalah tempat terbaik dalam proses mendidik dan bersosialisasi bagi anak. Selain itu, keluarga juga merupakan tempat pertama yang baik bagi pendidikan karakter anak.

Sebagai lingkungan pendidikan yang paling dekat dengan anak maka keikutsertaan atau kontribusi lingkungan anak dalam kesuksesan penanaman pendidikan karakter memiliki pengaruh yang sangat luar biasa. Melalui kedua orang tua, untuk pertamakalinya anak membentuk watak atau

\footnotetext{
${ }^{21}$ Ibid.

${ }^{22}$ Ibid., 46-49.
} 
kepribadian dalam mendapatkan pengarahan moral. Dalam seluruh kehidupan anak juga juga dilakukan dan dihabiskan dalam lingkungan keluarga. Oleh karena itulah pendidikan dalam lingkungan keluarga merupakan tempat pendidikan yang utama, serta dapat dikatakan sebagai fondasi dari pendidikan berikutnya. Keluarga yang harmonis, tentram, damai dan rukun akan menciptakan karakter yang baik. Jika sebaliknya, lingkungan yang tidak harmonis akan menciptakan anak yang akan melakukan tindakan diluar moral sebagaimana semestinya. ${ }^{23}$

Terdapat beberapa aspek yang perlu diperhatikan dalam pendidikan karaketer dalam lingkungan keluarga. 1) pola interaksi antar anggota keluarga. 2) pertumbuhan periode perkembangan anak. 3) pola asuh anak. 4) keteladanan dari orang tua.

1. Pola Interaksi antara Anggota keluarga

Pertama, pola interaksi dalam anggota keluarga. Hal ini diperlukan, karena manusia merupakan makhluk sosial dalam berinteraksi dengan orang lain. Sama halnya dengan keluarga, hubungan sosial dan interaksi seharusnya terjadi dalam keluarga. Dalam sebuah keluarga, terjalinnya interaksi bisa terjadi pada interaksi antara orang tua, interaksi antara orang tua dengan anak, interaksi antara anak dengan anak. Interaksi tersebut dapat memberikan pengaruh pada diri anak. Ini dikarenakan interaksi merupakan proses saling memberi pengaruh ini pada dasarnya juga merupakan proses pendididkan. Dalam interaksi antara anggota keluarga merupakan interaksi yang dilandasi oleh cinta kasih. ${ }^{24}$

Interaksi antarorang tua dalam konteks ini sangat menentukan kesuksesan dalam membentuk karakter anak dalam lingkungan keluarga. Terutama dengan cara menciptakan interaksi atau situasi yang edukatif dan mengandung unsur pendidikan. Dengan menciptakan interaksi seperti ini dapat melahirkan atau membentuk sikap positif yang bernilai pendidikan pada diri anak. Situasi interaktif ini tidak tercipta dengan sendirinya, akan tetapi harus dicipkan oleh ayah dan ibu agar anak-anak mereka menjadi manusia yang berkarakter baik berguna untuk masa depan mereka. ${ }^{25}$

Selanjutnya, intraksi antara orang tua dan anak. Hubungan yang terjadi antara orang tua dan anak bukanlah suatu hubungan kepemilikan, akan tetapi hubungan pemeliharaan. Oleh sebab itu, hubungan interaksi dan situasi yang terjadi pada anak dan orang tua merupakan hal yang sangat

\footnotetext{
${ }^{23}$ Agus Wibowo, Pendidikan Karakter: Strategi Membangun Karakter Bangsa Berperadaban (Yogyakarta: Pustaka Pelajar, 2012), 107-108.

${ }^{24}$ Salim Haitami, Pendidikan Agama Islam dalam Keluarga: Revitalisasi Peran Keluarga dalam Menyiapkan Generasi Bangsa yang Berkarakter (Yogyakarta: Arruzz Media 2013), 80.

${ }^{25}$ Haitami, Pendidikan Karakter, 765-66.
}

116 Jurnal El-Banat 
penting. Kualitas interaksi dan situasi ini sangat berpengaruh besar dalam proses perkembangan karakter pada diri anak tersebut. Hubungan interaksi dan situasi yang terjadi antara orang tua dengan anak biasanya berupa perkataan atau perbuatan. Akan tetapi tidak sedikit perkataan dan perbuatanperbuatan orang tua dapat menyebabkan anak menjadi stres dan tertekan bahkan sampai anak tersebut mengalami depresi berat. Beberapa prilaku yang dilakukan orang tua yang dapat menyebabkan hal tersebut terjadi di antaranya: ${ }^{26}$

Pertama, orang tua melarang anak menangis. Seluruh orang tua pasti sangat mendambakan anaknya menjadi sosok anak yang sangat luar biasa. Akan tetapi orang tua kerap kali tidak menyadari bahwa motivasi yang diucapkan justru tidak menjadikan anak menjadi termotivasi, sebaliknya hal itu malah membebani anak tersebut, bahkan bisa berakibat stres. Tekanan semacam ini biasanya terjadi pada anak laki-laki karena di Indonesia berkembang doktrin dari lingkungan yang menganggap bahwa anak laki-laki itu merupakan manusia yang paling kuat sehingga tidak boleh menunjukan kelemahan seperti menangis. ${ }^{27}$

Cara berpikir antara orang dewasa dan anak-anak tentu berbeda. Anak-anak cenderung hanya menyerap kata-kata secara langsung dan belum mampu memprosesnya dengan sempurna seperti orang dewasa. Misalnya, orang tua mengatakan kepada anak laki-lakinya "kamu tidak boleh menangis", sekilas memang kata-kata tersebut memang terlihat sepele dan kata-kata itu memang oleh orang tua diucapkan untuk motivasi pada anaknya supaya tidak cengeng. Akan tetapi dalam otak anak kata itu diserap sebagai bentuk perintah yang akan selalu terekam dalam otak anak hinggah dewasa. Masuknya perintah ini dalam otak anak akan membuat anak selalu menahan emosi kesedihannya dan tidak bisa menangis. Sehingga kejadian tersebut membuah anak menjadi stres karena tidak dapat meluapkan kesedihannya. Padahal menangis itu sebenarnya boleh-boleh saja, akan tetapi yang perlu dikontrol pada diri anak adalah frekuensi menangisnya. ${ }^{28}$

Kedua, perilaku atau sikap orang tua yang tidak konsisten. Berdasarkan penelitian, anak cenderung menyerap pelbagai hal dalam kehidupannya, di antaranya dapat melalui bahasa tubuh. Adapun orang tua yang selalu tidak konsisten akan membuat anak menjadi stres. Seharusnya orang tua harus bersikap secara tegas dalam mendidik anak. Bahasa tubuh yang dilakukan orang tua jika anak memperoleh masalah yang serupa,

\footnotetext{
26 Ibid., 66.

27 Ibid., 67-71.

28 Ibid.
} 
kadang orang tua bersikap baik dan kadang kala bersikap galak, itu dapat menyebabkan anak merasa tertekan. ${ }^{29}$

Ketiga, membeda-bedakan anak. Sering kali dijumpai orang tua yang secara tidak sadar suka membeda-bedakan anaknya. Meskipun dalam bentuk sikap dan perbuatan memang tidak terlihat akan tetapi dalam bentuk intonasi suara yang naik-turun ketika menghadapi kakak-beradik akan membuat anak merasakan bahwa adanya perbedaan sikap yang ditunjukan oleh orang tua. Intonasi suara ini lah yang akan menyebabkan anak mengalami tekanan karena merasa dibeda-bedakan oleh orang tua. ${ }^{30}$

Keempat, orang tua memberikan labeling pada diri anak. Salah satu hal yang sangat berbahaya pada diri anak yang dilakukan orang tua. Labeling ini biasanya dilakukan dengan memberi cap atau klain dari orang tua kpeada anak. Misalnya seperti, orang tua mengatakan "kamu anak pemalas", hal ini tentu akan sangat berdampak sangat luar biasa pada diri anak. Karena sang anak merasa mendapat klaim bahwa dirinya pemalas. Tentu ini akan membuat anak mengalami tekanan, stres, bahkan luka yang sangat mendalam hingga anak tersebut dewasa dan tentu akan berpengaruh terhadap karakter anak di masa depannya. ${ }^{31}$

Kelima, orang tua terlalu sering melarang anak. Ketika anak berada pada usia 4-6 tahun, saat itulah anak berada pada masa-masa kreatif dan rasa ingin tahu yang sangat besar terhadap berbagi hal dan meiliki keinginan dalam belajar yang sangat besar. Akan tetapi munculnya sikap kreatif dan rasa ingin tahu yang sangat besar dari anak ini dibatasi oleh orang tua. Karena orang tua menganggap itu merupakan suatu kenakalan sehingga mereka membatasi gerak mereka. Misalnya seperti "jangan main disana!". Meskipun orang tua memang meiliki tujuan baik, supaya sang anak tidak terluka atau sebaginya. Akan tetapi kata-kata larangan seperti "jangan" akan membuat anak menjadi stres dan mengalami tekanan. Karena anak merasa ruang kebebasan mereka dibatasi dan tidak bisa melakukan apa-apa. Sebiknya orang tua menggunakan istilah atau kata-kata lain yang menunjukan hal positif, sehingga anak dapat menerimanya dengan positif. Serta anak akan dapat memahami, bahwa jika melakukan tersebut akan membahasayakan dirinya sendiri, bukan karena orang tua tidak menyayangi mereka. Kalau terlalu sering mendapat larangan seperti itu, maka anak anak mencari-cari kesempatan untuk melakukan hal tersebut saat orang tua tidak mengetahuinya. ${ }^{32}$

\footnotetext{
${ }^{29}$ Ibid.

${ }^{30}$ Ibid.

${ }^{31}$ Ibid.

${ }^{32}$ Ibid.
}

118 Jurnal El-Banat 
Dengan demikian, perilaku-perilaku yang dilakukan oleh orang tua terhadap anak akan membuat anak menjadi stres, tertekan, depresi. Prilakuperilaku yang dilakukan oleh orang tua seperti itu akan menyebabkan anak menarik diri dari lingkungannya, menurunkan semangat belajar, konsentrasi berkurang, nilai-nilai pelajaran disekolah mengalami penurunan, tugas-tugas dari sekolah menjadi terabaikan karena pikiran anak merasa terbebani. ${ }^{33}$

Oleh karena itu orang tua juga harus memerhatikan beberapa hal agar dapat membangun intraksi atau hubungan yang baik dengan anaknya. Pertama, orang tua sebaiknya menempatkan dirinya sejajar dengan anaknya. Caranya dengan menempatkan dirinya sebagai sosok sahabat untuk anaknya. Kedua, orang tua sebaiknya menyediakan waktu luang yang berkualitas dengan anaknya untuk berinteraksi dan memanfaat kan setiap moment untuk menyelami perasaan anak, agar orang tau mampu memahami kondisi dan perasaan pada diri anaknya. Ketiga, seorang ibu sebaiknya mampu mengenali bahasa tubuh yang ada pada diri anak. Keempat, penting bagi orang tua memahami perasaan anak, hal ini sangatlah penting. Karena banyak terjadi antara anak dan orang tua mengalami "perang dingin", bahkan sampai anak kabur dari rumah karena orang tua tidak memahami perasaan anaknya. Kelima, supaya menjadi sosok orang tua yang ideal sebaiknya, orang tua menjadikan dirinya sebagai pendengar yang aktif dan baik, karena hal ini akan membuat anak merasa penting dan dihargai. Keenam, sebaiknya menjadi orang tua yang disiplin dan konsisten dalam melakukan hal dalam keluarga, karena orang tua adalah panutan bagi anakanak. $^{34}$

Interaksi antar anak, dalam interaksi yang terjalin antara adik dan kakak sebaiknya mengarah pada hal positif dan edukatif. Kualitas dalam interaksi antar anak dapat diketahui melalui tutur kata, perilaku sang anak dan tindakan atau sikap yang dilakukan mereka dalam bergaul sehari-hari di rumah. $^{35}$

2. Pertumbuhan dan Periode Perkembangan Anak.

Anak akan mengalami dua proses dalam kehidupannya secara terusmenerus, yaitu masa pertumbuhan dan perkembangan pada dirinya. Kedua proses tersebut saling berkaitan akan tetapi tidak dapat dipisahkan. Adapun definisi dari pertumbuhan adalah merupakan suatu proses yang berdasarkan fisiologisnya merupakan hasil dari proses pematangan pada fungsi-fungsi fisik yang terjadi secara normal, selain itu, dapat dikatakan ia merupakan suatu proses pematangan fisik pada tubuh manusia. ${ }^{36}$

\footnotetext{
${ }^{33}$ Ibid.

${ }^{34}$ Wibowo, Pendidikan Karakter, 121-122.

${ }^{35}$ Haitami, Pendidikan Karakter, 75-76.

${ }^{36}$ Ibid., 125-126.
} 
Sedangkan definisi dari perkembangan ialah pematangan pada diri manusia yang berupa non fisik atau tidak terlihat secara fisik. Perkembangan yang terjadi pada anak dapat ditunjang melalui beberapa faktor seperti lingkungan dan proses belajar dalam rentan waktu menuju kedewasaan. Oleh karena itu, potensi dan bakat dari diri anak harus benar-benar diperhatikan dalam pola asuh dan pendidikan yang anak tersebut peroleh. ${ }^{37}$ Dengan demikian, maka para orang tua semestinya membantu perkembangan anak hingga pada tingkat kedewasaan dengan membimbing agar anak dapat mengetahui moral dan sikap yang baik.

3. Pola Asuh Anak

Orang tua memang memiliki cara dan pola asuh yang khas. Antara keluarga satu dan keluarga lainnya memiliki cara atau pola yang berbedabeda. Adapun jenis-jenis pola asuh yang dilakukan orang tua terhadap anaknya ada beberapa jenis, yakni: Pertama, jenis pola asuh primitif yaitu merupakan jenis pola asuh yang sikap orang tua terhadap anaknya acuh atau bisa dikatakan tidak peduli. Jadi, segala sesuatu yang dilakukan oleh sang anak oleh orang tua diperbolehkan seperti tidak sekolah dan bandel. Pola prilaku yang dilakukan oleh anak yang seperti inilah biasanya disebabkan karena kedua orang tua sang anak sama-sama disibukkan dengan aktivitas bekerja dan anak hanya diberi harta dan materi. Sehingga sang anak merasa kurang perhatian dan tumbuh kembang yang terjadi pada diri sang anak tidak terkontrol. ${ }^{38}$

Kedua, jenis pola asuh otoriter yaitu merupakan jenis pola asuh dari orang tua terhadap anak yang bersifat memaksa, kaku dan semacamnya yang mana orang tua membuat segala jenis peraturan yang mana anak harus benar-benar mematuhinya tanpa memahami bagaimana perasaan anak tersebut. Apabila sang anak melakukan tindakan yang tidak diinginkan oleh orang tuanya, maka orang tuanya akan marah dan emosi. Bahkan sampai memberikan hukuman baik berupa mental ataupun fisik dengan alasan supaya mereka disiplin atas peraturan orang tua dan selalu menghormatinya. Dengan pola asuh seperti ini, justru akan membuat anak menjadi depresi berat, mudah sedih dan tertekan atas perlakuan orang tua terhadap dirinya. ${ }^{39}$

Ketiga, jenis pola asuh demokratis yaitu merupakan jenis pola asuh yang memberikan kebebasan pada diri anak dalam berkreasi di pelbagai hal yang sesuai dengan kemampuan sang anak, tentunya selama masih dalam batasan dan pengawasan orang tua. Jenis pola asuh seperti inilah yang sebaiknya diterapkan pada anak-anak. Karena pola asuh seperti ini akan

37 Kartini Kartono, Psikologi Anak (Psikologi Perkembangan) (Bandung: Mandar Maju, 1990), 21.

${ }^{38}$ Haitami, Pendidikan Karakter, 80-81.

${ }^{39}$ Ibid., 82 . 
menjadikan anak memiliki karakter yang mandiri, lebih percaya diri dan memiliki sifat peduli terhadap lingkungan. Dengan demikian, pola asuh yang salah dari orang tua terhadap anaknya akan berpengaruh besar terhadap pembentukan karakter pada diri anak. ${ }^{40}$

4. Teladan Orang tua

Teladan orang tua merupakan salah satu aspek yang seharusnya sangat diperhatikan, dalam pendidikan karakter dalam ruang lingkup keluarga. Berikut sebab-sebab orang tua merupakan teladan dalam menanamkan pendidikan karakter: Pertama, orang tua merupakan sosok pertama yang mengajarkan pendidikan pada diri anak. Kedua, sebagian besar anak mengabiskan waktunya bersama keluarga. Ketiga, orang tua dengan anak memiliki hubungan yang sangat erat. Keempat, hubungan interaksi antara anak dan orang tua itu bersifat benar-benar alami sehingga efektif dalam proses pembentukan karakter pada diri anak. ${ }^{41}$ Dengan demikian, segala sesuatu yang dilakukan oleh orang tua akan diserap oleh anak, hal ini dapat diibaratkan seperti spons, baik tindakan atau perilaku tersebut berupa perilaku baik maupun perilaku buruk.

\section{Pembentukan Nilai Karakter dalam Lingkungan Keluarga}

Dalam proses pembentukan atau penanaman pada diri anak bisa merefleksi pada delapan belas nilai yang dijelaskan sebelumnya. Berikut solusi dalam membentuk karakter anak yaitu: pertama, religius yaitu proses pembentukan atau penanaman nilai religus tidak hanya disalurkan melalui pelajaran saja. Ia dapat dilakukan melalui proses pembimbingan dengan cara menuntun dan mengarahkan, serta mendampingi anak. Dalam hal ini, keteladanan orang tua juga termasuk proses penanaman atau pembentukan nilai-nilai religius dalam diri. Sehingga segala sesuatu yang dilakukan oleh orang tua akan ditiru oleh anak. Misalnya orang tua yang rajin salat berjemaah di masjid dan mengaji, maka akan lebih mudah menyuruh anaknya dalam melakukan salat berjemaah dan mengaji. Begitu juga sama halnya dengan perilaku sopan-santun yang dilakukan oleh orang tua akan lebih mudah ditiru oleh anak. ${ }^{42}$

Kedua, jujur. Hal ini merupakan salah satu nilai yang sangat pentitng dalam mempengaruhi pembentukan atau penanaman nilai karakter pada dri sang anak, akan tetapi sangat sedikit orang tua yang memerhatikan soal kejujuran ini. Saat anak sudah dibentuk dengan kejujuran, maka ketika dewasa kelak nilai kejujuran ini akan tetap melekat pada dirinya. Berikut strategi yang dilakukan oleh orang tua dalam membentuk karakter jujur pada diri anak: 1) jangan membohongi anak. Kadang memang orang tua

\footnotetext{
${ }^{40}$ Wibowo, Pendidikan Karakter, 116-117.

${ }^{41}$ Haitami, Pendidikan Karakter, 84.

42 Ibid., 84-101.
} 
membohongi anak memang untuk suatu kebaikan. Misalnya seperti, supaya sang anak tidak menangis karena meminta suatu barang, maka orang tua menjanjikan barang tersebut akan tetapi ketika anak tersebut tidak menangis barang tersebut tidak diberikan. Dengan begitu anak akan berpikir bahwa dia telah dibohongi oleh orang tua, maka hal itu akan tetap membekas dalam dirinya hingga dewasa kelak. Karena anak merasa, bahwa sejak kecil anak tersebut sudah diajari untuk berbohong oleh orang tua. 2) hargai kejujuran anak. Jika kejujuran tidak dihargai oleh para orang tua maka anak akan merasa bahwa kejujuran itu tidaklah penting. Padahal sesungguhnya kejujuran itu amat sangatlah penting. 3) menanamkan kejujuran sejak masa anak-anak. Jika kejujuran sudah tertanam dan terbentuk maka dia akan menjadi manusia yang berkarakter jujur hingga dewasa kelak. 4) senantiasa memotivasi sang anak agar berperilaku jujur. ${ }^{43}$

Ketiga, toleransi merupakan nilai yang sangat berperan penting bagi orang tua dalam mendidik anak terutama ketika orang tua menanamkan nilai toleransi atau menghormati kepada sesama yang memiliki pemahaman yang berbeda dengan diri anak. Toleransi merupakan sikap atau kemampuan seseorang dalam menghargai perbedaan orang lain. Adapun cara orang tua agar dapat menanamkan atau membentuk sikap toleransi kepada anak, yaitu: Pertama, dengan cara menjadikan anak merasa dirinya itu spesial, aman dan dicintai. Kedua, menciptakan suasana dalam belajar di tempat yang baru, bersama orang-orang baru, dengan budaya yang berbeda. Serta perlunya penjelasan dari orang tua kepada anak agar memahami tentang banyaknya perbedaan yang ada dunia ini. Ketiga, senantiasa gunakan perkataan yang positif kepada anak, misalnya: "yang lembut ya ke adek, dia masih kecil, sangat mudah teluka." Serta hindari kata "jangan" atau tuduhan. Keempat, tunjukan kepada anak tentang belajar bersikap baik, sensitif dan menghormati orang lain dengan cara menjadikan orang tua sebagai teladannya. Seperti, berdiskusi dengan pikiran terbuka. ${ }^{44}$

Keempat, disiplin merupakan salah satu nilai karakter dalam membentuk diri anak. Oleh karena itu, bagi orang tua perlu memperhatikan beberapa hal. Pertama, orang tua harus konsisten dalam melakukan suatu hal. Kedua, dengan cara orang tua memberikan suatu peraturan kepada anaknya dengan aturan yang sederhana sehingga anak lebih mudah dalam melakukannya. Ketiga, sebaiknya orang tua tidak mengatur anak dihadapan orang lain karena sikap atau tindakan tersebut akan membuat anak merasa malu dan justru mempertahankan tingkah laku perilaku tersebut. Keempat, alasan dari tata tertib orang tua harus dijelaskan kepada anak sehingga anak dapat mengetahui alasan tersebut dan melakukannya dengan penuh

\footnotetext{
${ }^{43}$ Ibid.

${ }^{44}$ Ibid.
}

122 Jurnal El-Banat 
kesadaran. Kelima, apabila seorang anak melakukan hal yang positif maka sebaiknya berilah hadiah atau pujian. Tindakan ini dapat menumbuhkan rasa percaya diri pada sang anak. Keenam, dalam memberikan suatu hukuman kepada anak, sebaiknya orang tua tidak melibatkan kekerasan fisik atau jiwa anak. Ketujuh, sebaiknya orang tua bersikap tegas kepada anaknya, tegas yang maksud di sini adalah tidak menggunakan kekerasan fisik. ${ }^{45}$

Kelima, kerja keras merupakan salah satu nilai karakter yang sangat dibutuhkan oleh anak dalam membentuk karakter. Dalam menanamkan nilai ini, anak perlu diberikan penjelasan bahwa agar dapat mendapatkan uang maka harus berkerja keras. Tanpa uang maka tidak bisa memenuhi kebutuhan sehari-hari. Selain itu, dengan cara menjelaskan uang merupakan hasil dari jerih payah maka anak akan mejadi lebih berpikir dan lebih berhati-hati dalam meminta suatu hal. ${ }^{46}$

Keenam, kreatif merupakan salah satu nilai karakter yang sangat dibutuhkan oleh anak dalam membentuk karakter. Dalam menanamkan karakter ini, hal yang patut dilakukan orang tua di antaranya: Pertama orang tua memberikan ruang yang besar kepada anak agar dapat bebas berkreasi yang bertujuan supaya anak tidak takut bertanya, berpendapat dan berani mecoba sesuatu. Kedua, orang tau memberikan dorongan kepada anak terkait kegiatan diluar pelajaran sekolah seperti yang berkaitan dengan minat dan hobinya. Ketiga, orang tua sebaiknya memberikan lebih banyak dorongan kepada sang anak dan mengurangi larangan. Perkataan larangan dari orang tua inilah yang akan menyebabkan sang anak merasa dibatasi dalam mencoba sesuatu dalam berkreativitas. Keempat, sebaiknya orang tua senantiasa memberikan apresiasi kepada anak atas kerja kerasnya sehingga dengan beginilah anak akan merasa nyaman, berinisatif, dalam mencoba dan berkarya. ${ }^{47}$

Ketujuh, mandiri. Hal ini merupakan salah satu nilai yang sangat dibutuhkan oleh anak dalam membentuk karakter. Cara dalam menanamkan mandiri pada anak yaitu: Pertama, sebaiknya orang tua tidak mengajarkan sesuatu kepada anak jika merasa anak mampu melakukannya sendiri. Karena jika mengajari anak padahal sang anak tersebut mampu, maka sama halnya dengan membangun ketidak mandirian sang anak. Kedua, dengan menetapkan waktu tidur bagi anak dan belajar tidur sendiri tanpa didampingi oleh orang tua.

Kedelapan, demokratis merupakan salah satu nilai karakter yang sangat dibutuhkan oleh anak dalam membentuk karakter. Sikap demokratis ini memerlukan kerelaan dalam nedengarkan serta menghadapi pendapat

\footnotetext{
${ }^{45}$ Ibid.

${ }^{46}$ Ibid.

${ }^{47}$ Ibid.
}

El-Banat Vol. 9. No.1, Januari-Juni 2019123 
dari orang lain. Dalam hal ini, orang tua harus mencontohkan kepada anaknya dengan cara selalu mendengarkan pendapat dari anak serta menyadari bahwa pendapat orang dewasa tidaklah selalu benar dan menang. ${ }^{48}$

Kesembilan, rasa ingin tahu merupakan salah satu nilai karakter yang sangat dibutuhkan oleh anak dalam membentuk karakter. Manusia pada dasarnya memang memiliki rasa ingin tahu yang sangat bersar,rasa ingin tahu ini lah yang dapat menyebabkan anak bertambah ilmu pengetahuannya. Mulanya memang anak memiliki rasa keingintahuan yang sangat besar. Seiring sengan perkembangan teknologi seperti "google" yang berisikan segala sesuatu ada di dalamnya. Banyak peristiwa yang mulanya anak tidak berniat melihat konten negatif akan tetapi justru yang keluar konten yang tidak sesuai dengan usianya. Oleh karena itulah, sebenarnya boleh saja apabila anak dikenalkan dengan teknologi, akan tetapi sebaiknya tetap dalam pengawasan orang tua supaya anak tidak terpengaruh dengan hal-hal negatif yang ada pada internet.

Kesepuluh, semangat kebangsaan merupakan salah satu nilai karakter yang sangat dibutuhkan oleh anak dalam membentuk karakter. Dalam menanamkan karakter ini, orang tua dapat mengajak anak ke tempattempat liburan yang mengandung unsur kebangsaan seperti museum dan lain sebagainya. ${ }^{49}$

Kesebelas, cinta tanah air merupakan salah satu nilai karakter yang sangat dibutuhkan oleh anak dalam membentuk karakter. Melihat kondisi pada saat ini, tingkah laku pada diri anak. Anak-anak lebih menyukai perilaku yang kebarat-baratan. Oleh karena itulah, penting untuk orang tua dalam mengenalkan sesuatu yang menunjukan kebanggan dari Indonesia. Misalnya seperti mengajarkan rasa bangga jika memakai pakaian batik, karena batik merupakan produksi dalam negeri dan merupakan warisan para leluhur di Indonesia.

Kedua belas, menghargai prestasi merupakan salah satu nilai karakter yang sangat dibutuhkan oleh anak dalam membentuk karakter. Hal yang dapat dilakukan dalam menanamkan karakter ini adalah dengan memberikan penghargaan berupa hadiah atau rewards kepada anak apabila anak mendapat prestasi. Pemberian penghargaan dari orang tua kepada anak merupakan bentuk kebanggaan dari orang tua kepada anak, serta kebanggan anak terhadap orang tua. ${ }^{50}$

Ketiga belas, bersahabat dan komunikatif merupakan salah satu nilai karakter yang sangat dibutuhkan oleh anak dalam membentuk karakter.

\footnotetext{
${ }^{48}$ Ibid.

${ }^{49}$ Ibid.

${ }^{50}$ Ibid.
}

124 Jurnal El-Banat 
Dengan bergaul maka akan memberikan dampak positif pada anak. Adapun cara orang tua agar anak dapat mudah bergaul adalah dengan cara: 1) dengan mengadakan pesta di rumah, dengan mengundang banyak teman maka hal ini akan membuat anak memiliki banyak teman. 2) selalu ajak anak agar terlibat dengan permainan yang banyak temannya. 3) mengajak anak agar belajar kelompok. 4) orang tua mengajak anaknya agar selalu berbagi terhadap teman-temannya.

Keempat belas, cinta damai. ini merupakan salah satu nilai karakter yang sangat dibutuhkan oleh anak dalam membentuk karakter. Dalam penanaman karakter ini orang tua harus benar-benar menjadi refleksi bagi anaknya. Oleh karena itu sebaiknya orang tia menghindari sikap pertengkaran dihadapan anaknya. ${ }^{51}$

Kelima belas, gemar membaca merupakan salah satu nilai karakter yang sangat dibutuhkan oleh anak dalam membentuk karakter. Jika memikirkan persoalan masa depan anak. Maka membaca merupakan hal yang sangat berpengaruh. Hal sebaiknya dilakukan oleh orang tua adalah dengan membacakan buku kepada anaknya. hal ini akan menyebabkan anak terbiasa dengan bahasa buku. Ketika sedang membacakan buku, anak bertanya tentang kata baru yang didengarnya, maka secara tidak langsung anak tersebut belajar. Kemudian memilihkan buku yang cocok untuk bacaan anaknya. Setelah itu memberikan buku yang anak gemari.

Keenam belas, peduli lingkungan, merupakan salah satu nilai karakter yang sangat dibutuhkan oleh anak dalam membentuk karakter. Anak adalah generasi yang mewarisi keberlangsungan bumi. Di sini lah, perlunya orang tua mengenalkan kepada anak bahwa bumi merupakan ciptaan Allah, harus dilestarikan atau dipelihara dan memanfaatkan dengan sebaik mungkin. Dalam proses mengenalkan ini bisa dilakukan dengan cara berdiskusi bersama anak. Dengan demikian, kebiasaan dalam memelihara lingkungan akan tetap terjaga sampai anak tersebut tumbuh dewasa. ${ }^{52}$

Ketujuh belas, peduli sosial merupakan salah satu nilai karakter yang sangat dibutuhkan oleh anak dalam membentuk karakter. Dalam hal ini, yanng dilakukan orang tua adalah: 1) orang tua dapat mengajak anaknya untuk menjenguk orang yang sedang sakit. 2) mengajak anak agar mengunjungi panti jompo. 3) orang tua mengajarkan kepada anaknya tentang pentingnya dalam bersedekah dan masih banyak lagi.

Kedelapan belas, tanggung jawab merupakan salah satu nilai karakter yang sangat dibutuhkan oleh anak dalam membentuk karakter. Dalam menanamkan nilai karakter ini dapat dilakukan dengan cara membagi tugas rumah pada anak. Hal ini dapat melatih dii anak menjadi sosok yang

\footnotetext{
${ }^{51}$ Ibid.

${ }^{52}$ Ibid.
} 
bertanggung jawab atas pekerjannya. Demikian nila-nilai pendidikan karakter yang perlu dibentuk pada diri sang anak di lingkungan keluarga. Baik buruknya karakter ini akan berpengaruh terhadap diri anak tersebut ketika dewasa nanti. ${ }^{53}$

\section{Implementasi Pendidikan Karakter di Lingkungan Sekolah dan Masyarakat}

Dalam hal ini meliputi beberapa aspek yaitu: Pertama pembenahan kurikulum disekolah dengan memasukan nilai-nilai dalam pendidikan karakter pada tiap-tiap mata pelajaran di sekolah. Kedua memperbaiki kopetensi kinerja dan karakter guru karena guru merupakan teladan bagi anak selama anak berada dalam sekolah. Ketiga, pengintegrasian budaya di sekolah. Adapun dampak pendidikan karakter itu sendiri juga berpengaruh terhadap keberhasilan akademis anak. Dengan pendidikan karakter maka anak akan menjadi cerdas secara emosi. Kecerdasan emosi inilah yang akan menyebabkan anak mampu dalam menghadapi masa depan. Anak-anak yang memiliki masalah dalam kecerdasan emosinya akan mengalami kesulitan belajar, kesulitan bergaul dan tidak mampu mengontrol emosinya. Berdasarkan penelitian, dari Daniel Goelman tentang keberhasilan, menghasilkan kesimpulan bahwa di masyarakat $80 \%$ orang dipengaruhi oleh kecerdasan emosi dan $20 \%$ kecerdasan otak (IQ). ${ }^{54}$

Dalam pendidikan karakter di lingkungan sekolah, jika dikaitkan dengan revolusi mental sama pentingnya dengan pendidikan karakter. Revolusi mental ini merupakan konsep yang ditawarkan presiden Republik Indonesia. Presiden pernah menuliskan definisi revolusi mental ini adalah sebagai menciptakan paradigma budaya politik dan pendekatan nation building baru yang lebih manusiawi, sesuai dengan budaya di nusantara. Dalam penjabarannya ada tiga dimensi pembangunan manusia di Indonesia yaitu: sehat, cerdas dan berkepribadian. Dalam hal ini anak-anak tidak terlalu membutuhkan kurikulum, akan tetapi mereka benar-benar membutuhkan kehidupan yang benar-benar mampu menghidupi mereka. Jadi, revolusi mental ini membangun mental anak bangsa yang baik dalam bangsa dan bernegara yang bebas korupsi. Hal ini harus dimulai sejak sekolah dasar, anak harus sudah dibiasakan bersikap jujur. Di mana pada sekolah dasar dalam revolusi mental ini lebih menekankan pendidikan karakter $80 \%$ dan pengetahuan $20 \%$ pada sekolah dasar. ${ }^{55}$

\footnotetext{
53 Ibid.

${ }^{54}$ Muchlic Masnur, Pendidikan Karakter: Menjawab Tantangan Krisis Multi Dimensional (Jakarta: Bumi Aksara, 2011), 29-30.

${ }^{55}$ Kristiawan Muhammad, "Telaah Revolusi Mental dan Pendidikan Karakter", Ta'dib, vol. 18, no.1, (2015), 14-15.
} 
Dalam penanaman karakter pada pendidikan karakter di lingkungan masyarakat meliputi tiga aspek. Pertama, pengkondisian lingkungan masyarakat. Dalam hal ini seharusnya orang tua memilih lingkungan yang baik agar dapat mendukung proses pembentukan karakter pada diri anak. Kedua, sarana-sarana pendidikan karakter di lingkungan masyarakat, yakni seperti tempat-tempat beribadah, perpustakaan daerah maupun letak lembaga pendidikan sekitar. Ketiga, keteladanan pemimpin, tokoh agama dan tokoh masyarakat. ${ }^{56}$

\section{Penutup}

Pendidikan karakter dapat diterjemahkan sebagai seluruh tingkah laku ataupun perbuatan dari orang yang lebih tua terhadap yang lebih muda terhadap nilai-nilai pengetahuan, pengalaman yang kesemuanya bertujuan untuk membangun suatu sikap, mentalitas dan perbuatan yang berkaitan dengan Tuhan. Masa anak di sekolah dasar merupakan suatu masa keemasan (golden age) di mana pada masa itu anak mulai membentuk karakter yang baik pada dirinya dan pembentukan karakter ini dipengaruhi oleh beberapa hal yakni, keluarga, sekolah dan lingkungan. Nilai-nilai deskripsi pendidikan karakter pada diri anak ada delapan belas karakter yaitu: religius, jujur, toleransi, disiplin, kerja keras, kreatif, mandiri, demokratis, rasa ingin tahu, semangat kebangsaan, cinta tanah air, menghargai prestasi, bersahabat, cinta damai, gemar membaca, peduli lingkungan, peduli sosial, tanggung jawab. Adapun aspek-aspek pendidikan karakter pada lingkungan keluarga yaitu: pola interkasi, pertumbuhan periode perkembangan anak, pola asuh anak, keteladanan orang tua.

\section{Daftar Rujukan}

Andre (Guru SD Khazanah Ilmu), Wawancara, Sidoarjo, 23 oktober 2018.

Haitami, Salim Pendidikan Karakter: Konsepsinya terpadu di Lingkungan Keluarga, Sekolah, Perguan Tinggi, Masyarakat. Yogyakarya: ArRuzz Media, 2013.

------. Pendidikan Agama Islam dalam Keluarga: Revitalisasi Peran Keluarga dalam Menyiapkan Generasi Bangsa yang Berkarakter. Yogyakarta: Arruzz Media 2013.

Jumarudin et al., "Pengembangan Model Pembelajaran Humanis Religius", Pengembangan Pendidikan, vol. 2, no. 2, 2014.

Kartono, Kartini. Psikologi Anak (Psikologi Perkembangan). Bandung: Mandar Maju, 1990.

Masnur, Muchlic. Pendidikan Karakter: Menjawab Tantangan Krisis Multi Dimensional. Jakarta: Bumi Aksara, 2011.

Muhammad, Kristiawan. "Telaah Revolusi Mental dan Pendidikan Karakter”, Ta'dib, vol. 18, no.1, 2015.

\footnotetext{
${ }^{56}$ Haitami, Pendidikan Karakter, 101.
} 
Mustofa, Imron. "Ulama' dan Kontestasi Pengetahuan dalam Sudut Pandang Al Qur'ān", Jurnal Pendidikan Agama Islam (Journal of Islamic Education Studies), vol. 5, no. 1, 2017.

Nasional, Departemen Pendidikan. Kamus Besar Bahasa Indonesia. Jakarta: Gramedia Pustaka Utama, 2011.

Wibowo, Agus. Pendidikan Karakter: Strategi Membangun Karakter Bangsa Berperadaban. Yogyakarta: Pustaka Pelajar, 2012.

Zubaedi, Desain Pendidikan Karakter: Konsepsi dan Aplikasinya dalam Lembaga Pendidikan. Jakarta: Kencana, 2011. 